\title{
Algorithm for evaluating the effectiveness of a high-rise development project based on current yield
}

\author{
Elena Soboleva ${ }^{1, *}$ \\ ${ }^{1}$ Moscow State University of Civil Engineering, Yaroslavskoye sh. 26, Moscow, 129337, Russia
}

\begin{abstract}
The article is aimed at the issues of operational evaluation of development project efficiency in high-rise construction under the current economic conditions in Russia. The author touches the following issues: problems of implementing development projects, the influence of the operational evaluation quality of high-rise construction projects on general efficiency, assessing the influence of the project's external environment on the effectiveness of project activities under crisis conditions and the quality of project management. The article proposes the algorithm and the methodological approach to the quality management of the developer project efficiency based on operational evaluation of the current yield efficiency. The methodology for calculating the current efficiency of a development project for high-rise construction has been updated.
\end{abstract}

\section{Introduction}

To solve the problem of operational evaluation of the current efficiency of the development project for high-rise construction and further management, an algorithm is proposed based on the current yield of a project as a tool for monitoring the implementation of the project. To determine the effectiveness of a development project, it is necessary to carry out a performance analysis, which is defined as the ratio of the achieved result to costs spent to obtain it. The use of performance metrics has allowed to develop a certain efficiency management algorithm [1].

\section{Methods}

Periodic updating of the economic and financial model of a development project reveals a change in pre-defined indicators, which requires an improvement in the evaluation of current efficiency. To solve the problem of the operational management mechanism for evaluating the effectiveness of the high-rise building project, it is proposed to consider the main implementation factors and efficiency factors.

The first stage involved drawing up a chain of economic and organizational ties for the implementation of the development project. in accordance with a comprehensive

* Corresponding author: alenas_06@mail.ru 
analysis of project practices, the tasks of the development project are structured (Table 1) to determine the share in the formation of the factors for the condition of aim achievement.

Table 1. The objectives of a high-rise construction development project

\begin{tabular}{|l|l|}
\hline \multicolumn{1}{|c|}{ The name of objective of the high-rise construction development project } & Designation \\
\hline Professional support of the project & DPO-1 \\
\hline $\begin{array}{l}\text { Professional definition of the project strategy and development of the technical } \\
\text { project }\end{array}$ & DPO -2 \\
\hline $\begin{array}{l}\text { Providing control over the development of the project and the schedule for the } \\
\text { construction of real estate }\end{array}$ & DPO -3 \\
\hline Formation of the budget of the development project & DPO -4 \\
\hline $\begin{array}{l}\text { Ensuring control over the implementation, optimization and minimization of the } \\
\text { budget of the development project }\end{array}$ & DPO -5 \\
\hline Maximum reduction in construction terms & DPO -6 \\
\hline Ensuring control over maintaining the quality of construction of facilities & DPO -7 \\
\hline Achieving optimal project efficiency & DPO -8 \\
\hline $\begin{array}{l}\text { Protecting the interests of the investor to subcontractors and government } \\
\text { agencies }\end{array}$ & DPO -9 \\
\hline Preventing the situation of increasing cost and reduction of quality & DPO -10 \\
\hline
\end{tabular}

The factors were defined that in one respect are based on the main objectives of the development project, and in other respect are the basis for determining the factors of the project's effectiveness. The pyramid of forming the tasks of a high-rise development project is made. An analysis of the conducted survey of developers enabled to express the effectiveness of the tasks of the project.

$$
E_{D P T}=f\left[\left(R_{d p} ; Q_{d p} ; T_{d p}\right) *(\alpha ; \beta ; \gamma)\right] \Rightarrow \max
$$

where: $R_{d p}$ is obtaining greater results at lower costs, $Q_{d p}$ is creating a quality product, specifically the construction facility, $T_{d p}$ is obtaining the maximum planned result on time; $E_{D P T}$ is effectiveness of the tasks of the development project; $\alpha, \beta, \gamma$ are coefficients of execution of components at all stages of the life cycle of the development project [2].

At the third stage, the author proposes to determine the factors for the implementation of the development project, which are the driving force behind the effectiveness of the project. The author defines the factors for the implementation of the development project as the fundamental driving characteristics of the organization and functioning of the project, which establish its life cycle and the effectiveness of the results (Table 2).

Table 2. Implementation factors for the high-rise construction development project

\begin{tabular}{|l|l|l|l|l|}
\hline $\mathbf{N}$ & & Factor name & Influence on the result of the project & $\begin{array}{l}\text { Impact } \\
\text { share, } \\
\text { \% }\end{array}$ \\
\hline 1 & $\mathrm{Fp}$ & $\begin{array}{l}\text { Creating an effective } \\
\text { team of professionals } \\
\text { for project management }\end{array}$ & $\begin{array}{l}\text { Ensuring the successful implementation of all } \\
\text { stages of the development project and quality } \\
\text { control of the project being implemented. }\end{array}$ & 3 \\
\hline 2 & $\mathrm{Fr}$ & $\begin{array}{l}\text { Level of detailed real } \\
\text { estate market research }\end{array}$ & $\begin{array}{l}\text { Allows determining the existing supply-demand } \\
\text { ratio in different market sectors. }\end{array}$ & 20 \\
\hline 3 & $\mathrm{Ft}$ & $\begin{array}{l}\text { Full accounting of } \\
\text { cycles when choosing } \\
\text { the time of } \\
\text { implementation of the } \\
\text { development project }\end{array}$ & $\begin{array}{l}\text { Development projects are long-term, therefore } \\
\text { it is necessary to take into account the patterns } \\
\text { in the development of the real estate market }- \\
\text { cyclicality: the beginning of the project should } \\
\text { accrue to activity decay, the finishing of the }\end{array}$ & 5 \\
\hline
\end{tabular}




\begin{tabular}{|c|c|c|c|c|}
\hline & & & project - to the peak of activity. & \\
\hline 4 & Fl & $\begin{array}{l}\text { Qualitative choice of } \\
\text { the location of the } \\
\text { future development } \\
\text { project }\end{array}$ & $\begin{array}{l}\text { The location factor is the key in the formation } \\
\text { of the sale price and the speed of } \\
\text { implementation. }\end{array}$ & 4 \\
\hline 5 & $\mathrm{Ff}$ & $\begin{array}{l}\text { Reasonable choice of } \\
\text { the way of financing of } \\
\text { the development project }\end{array}$ & $\begin{array}{l}\text { Observe the proportion between own and } \\
\text { borrowed funds, where own at the start-up stage } \\
\text { should not be less than } 10 \% \text {. }\end{array}$ & 10 \\
\hline 6 & $\mathrm{Fa}$ & $\begin{array}{l}\text { Application of the } \\
\text { competitive approach at } \\
\text { all stages of the } \\
\text { development project }\end{array}$ & $\begin{array}{l}\text { Executors for each stage of the development } \\
\text { project should be carefully selected on a } \\
\text { competitive basis }\end{array}$ & 1 \\
\hline 7 & Fs & $\begin{array}{l}\text { Systematic control over } \\
\text { compliance with the } \\
\text { implementation } \\
\text { deadlines }\end{array}$ & Affects the project payback and cost over time & 7 \\
\hline 8 & $\mathrm{Fq}$ & $\begin{array}{l}\text { Availability of a quality } \\
\text { management system }\end{array}$ & $\begin{array}{l}\text { Provides the final result of the project and } \\
\text { removes reputational risks of the developer }\end{array}$ & 15 \\
\hline 9 & $\mathrm{Fv}$ & $\begin{array}{l}\text { Qualitative calculation } \\
\text { and control of } \\
\text { investment costs and } \\
\text { sale values of a } \\
\text { production unit }\end{array}$ & $\begin{array}{l}\text { Directly affects the overall objective of the } \\
\text { project }\end{array}$ & 25 \\
\hline $\begin{array}{l}1 \\
0\end{array}$ & Fp & $\begin{array}{l}\text { Timeliness of } \\
\text { preparation of the } \\
\text { subsequent stages }\end{array}$ & $\begin{array}{l}\text { All stages of the development project should be } \\
\text { carefully calculated and planned }\end{array}$ & 10 \\
\hline
\end{tabular}

To determine the effectiveness of the development project, the method of multicriteria evaluation of alternatives is applied using a procedure of ranking by several indicators. Based on the survey conducted and the experimental data of the research of development projects, the factors are ranked by the value of the necessary impact on the result of the project. There were obtained the following key factors determining the efficiency of the development project: realization price (Fi) and the investment cost $(\mathrm{Fc})$ of the square meter of the sold area of the facility being constructed under the development project [3].

\section{Results}

The main tools of project performance management are methodologically expressed through the design ratio - the current yield index of the development project. When evaluating the effectiveness of projects, the index of investment yield is used, which is determined as the ratio of the sum of the cash flow elements from operating activities to the absolute value of the sum of the elements of the cash flow from investment activity. Initial planned and further actual data on the project in the process of its implementation are recorded in the economic and financial model of the high-rise development project [4].

The yield index is an indicator of the return of investments, defined relatively to the total indicators of net cash flow and investments for the economic life of their investments. Estimation of the current yield $Y_{i}$ is the momentary evaluation of the profitability of the development project in a specific period of time through the indicators: $V_{\text {real }(i)}$ - the price or market value of the facility under construction, $P_{\text {act }(i)}$ - the actual investment prime cost of the facility under construction, $C_{n e s s(i)}$ - the remaining costs at the current time $(i)$ necessary to complete the construction and installation works on the development project facility 
under construction. A graphic model for assessing the current efficiency of a development project within the management time-frame is proposed (Fig. 1)

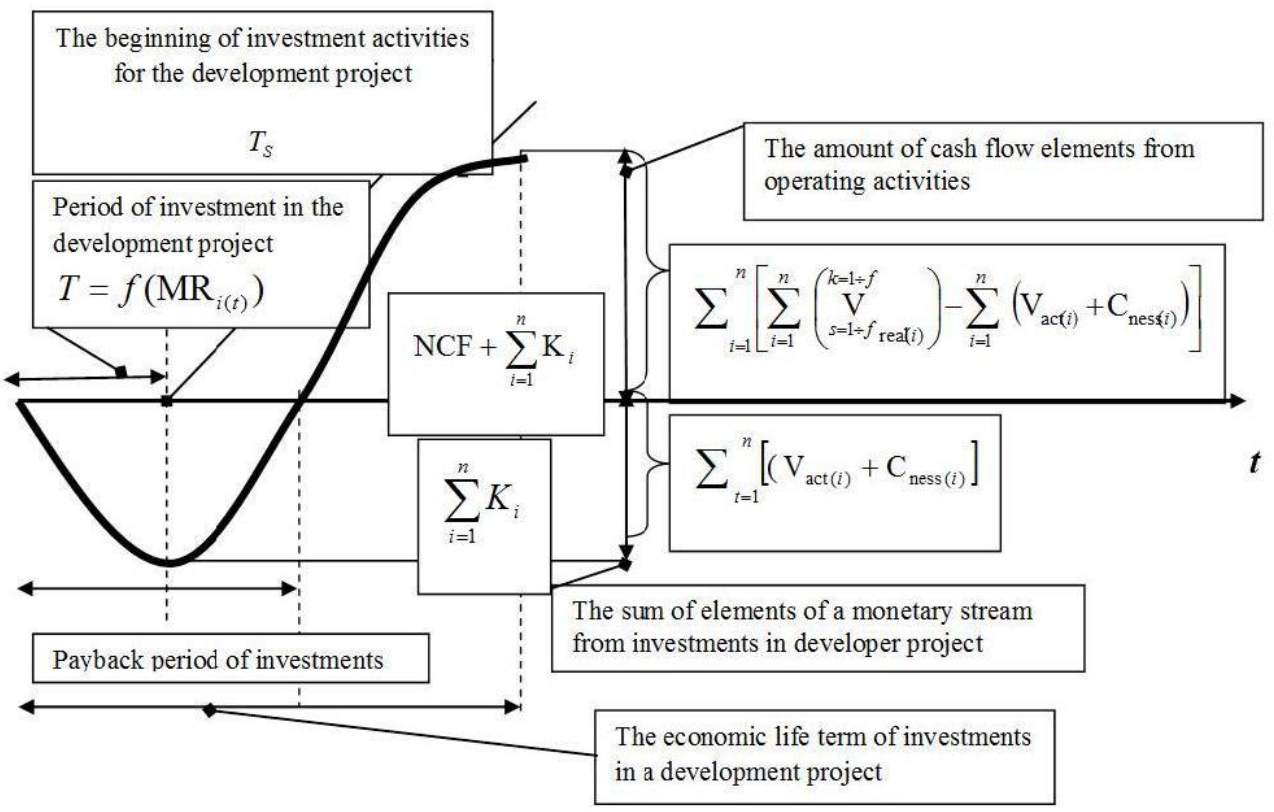

Fig. 1. Graphical model for assessing the current efficiency of a high-rise construction project during the life-cycle management time-frame in a development

The start of the investment activity $\mathrm{T}_{\mathrm{S}}$ on the development project depends on the investment period:

$$
T=f\left(\mathrm{YP}_{i(t)}\right)
$$

where: $t$ is the period of implementation of the development project, which includes all stages of the life cycle, taking into account the time-frame of operational management of the development project. Money resources entering the development project:

$$
\sum_{i=1}^{n} \mathrm{MR}_{i(t)}=\sum_{i=1}^{n} \mathrm{~V}_{s i \text { real }(i)}^{k i}+\sum_{i=1}^{n} \mathrm{~K}_{i}
$$

where: $\mathrm{K}$ is the volume of investment of the development project. The author offers the conditions for determining and forming the price for the implementation of the development project facility under construction [4].

$$
\begin{aligned}
& \mathrm{V}_{\text {real }(f-g(i))}=\sum_{i=1}^{n}\left(\sum\left(\mathrm{V}_{\substack{\text { real }(f(i)) \\
s 1}}^{k 1}+\mathrm{V}_{\substack{\text { real }(j(i)) \\
s 2}}^{k 1}+\mathrm{V}_{\text {real }(g(i)))}^{k 3}\right)+\right.
\end{aligned}
$$

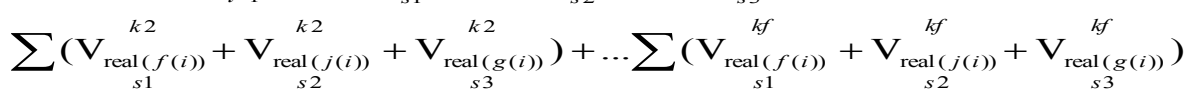

where: $\mathbf{k}$ is the object class. Several classes of real estate objects are possible from 1 to $\mathrm{f}$ (economy, economy-plus, average, business); $\mathbf{s}$ is the object status; $\mathbf{s f}$ is the number of statuses in accordance with the number of classes of real estate objects; $\mathbf{s} 1$ is the status of the object at the state of readiness of the real estate development project facility $35-60 \%$; s2 is the status of the object at the state of readiness $61-80 \%$; $\mathbf{s} 3$ is the status of the object at the state of readiness $81-100 \%$; $\mathbf{V}$ real(f(i)) is the implementation value of the real estate development project facility under construction at the state of readiness $35-60 \%$; $\mathbf{V}_{\text {real }(j(i))}$ is the implementation value of the real estate development project facility under construction 
at the state of readiness $61-80 \% ; \mathbf{V}_{\text {real(g(i)) }}$ is the implementation value of the real estate development project facility under construction at the stage of readiness $81-100 \%$ [5].

The solution of the problem of an operational evaluation of the high-rise development project current efficiency involves using a generalized indicator, the investment cost. It designates a unit of production - a square meter of the sold area of the real estate object, which represents the total costs expended at all stages of the life cycle of the development project. The author proposes the method of forming and controlling the change in the investment cost of the real estate object under construction within the framework of the project.

$$
\begin{aligned}
& \mathrm{P}_{\text {invest(t) }}=\frac{\mathrm{P}_{\text {act( }(\mathrm{i})}+\mathrm{C}_{\text {ness }(i)}}{\sum_{i=1}^{n} S_{\text {real }(i)}^{k i}}= \\
& \sum_{i=1}^{n}\left(\left(\mathrm{P}_{\text {con } \& \text { inst }(i)}^{\text {act }}+\mathrm{C}_{\text {con \&inst }(i)}^{\text {ness }}\right)+\left(\mathrm{P}_{\text {techcust }(i)}^{\text {act }}+\mathrm{C}_{\text {techcust }(i)}^{\text {nes }}\right)+\left(\mathrm{P}_{\text {overh }(i)}^{\text {act }}+\mathrm{C}_{\text {overh }(i)}^{\text {ness }}\right)+\left(\mathrm{P}_{\text {real }(i)}^{\text {act }}+\mathrm{C}_{\text {real }(i)}^{\text {ness }}\right)+\right. \\
& =\frac{\left.+\left(\mathrm{P}_{\operatorname{design}(i)}^{\text {act }}+\mathrm{C}_{\mathrm{design}(i)}^{\text {ness }}\right)+\left(\mathrm{P}_{\operatorname{dev}(i)}^{\text {act }}+\mathrm{C}_{\operatorname{dev}(i 0}^{\text {ness }}\right)+\left(\mathrm{P}_{\text {loan }(i)}^{\text {act }}+\mathrm{C}_{\operatorname{loan}(i)}^{\text {ness }}\right)\right)}{\sum_{i=1}^{n} S_{\text {real }(i)}^{k i}}
\end{aligned}
$$

where: $S_{\text {real }}$ is area for the sale of real estate buildings under construction; $C_{\text {condinst }}$ is costs for construction and installation work; $C_{\text {techcust }}$ is direct costs of the construction technical customer; $C_{\text {overh }}$ - overhead costs of the construction technical customer; $C_{\text {sale }}$ - costs for the sale of the real estate buildings under construction including advertising and marketing; $C_{\text {design }}$ the costs of designing real estate buildings under construction; $C_{d e v}$ - developer management costs; $C_{\text {loan }}$ - costs for the loan debt of the project. Then the index of current profitability is determined by this formula:

$$
\mathrm{Y}_{i}=\frac{\mathrm{V}_{i}-\left(\mathrm{P}_{\mathrm{act}(i)}+\mathrm{C}_{\mathrm{ness}(i)}\right)}{\left(\mathrm{P}_{\mathrm{act}(i)}+\mathrm{C}_{\mathrm{ness}(i)}\right)}=\frac{\mathrm{V}_{i}}{\left(\mathrm{P}_{\mathrm{act}(i)}+\mathrm{C}_{\mathrm{ness}(i)}\right)}-\mathbf{1}
$$

The dynamics of the current yield index and the interrelation of the parameters $P_{\text {act }}(i)$, $C_{\text {ness }(i),} V_{\text {real }(i)}$ are analyzed and presented graphically by the example of a development project of the complex development of a territory with the construction of residential real estate in area $200000 \mathrm{~m}^{2}$, commercial premises and social infrastructure [6].

\section{Discussions}

Thus, the development project of high-rise construction is considered as sustainable and effective within the implementation process assuming that the inequality is fulfilled: $Y_{i}>Y^{k}{ }_{(i)}$. Therefore, the index of the current yield of the development project should be above zero. In case of inequality: $Y_{i}<Y^{k}{ }_{(i)}$ at the state of the real estate object construction readiness $80-100 \%$, a program is being developed to stabilize the development project through the project's managed parameters: the sale price and residual project costs. In case of a stable situation, it is recommended to conduct similar temporary monitoring of the development project before the end of its final stage. The control calculation with unstable financing of the development project should be performed monthly, with stable financing and execution of the terms - quarterly.

\section{Conclusion}

The management of high-rise development project efficiency involves a set of management processes: planning, execution arranging, monitoring and analysis. These processes strategically determining the mission enable the developer to assess and manage the project 
implementation activities fast in order to achieve the goals under appropriate usage of available resources. The management system is based on the principles of cost management.

\section{References}

1. E. Nezhnikova R. Obukhov MATEC Web of Conferences 10608025 (2017) doi: 10.1051/matecconf/201710608025

2. I.V. Ilin, V.I. Koposov, A.I. Levina, Model of asset portfolio improvement in structured investment products, Life Science Journal, 11, pp 265-269 (2014)

3. K. Olga, An innovative approach to the formation of a progressive taxation probabilistic model on personal incomes, Intern. Journal of Economics and Financial Issues, Vol 6, IS 3, pp 995- 1002 (2016)

4. A.K. Orlov, Arrangement and planning of developer's activities in the course of construction megaprojects implementation MATEC Web of Conferences 106, (2016)

5. V. Kankhva, Procedia Engineering $165 \quad 1300-1304 \quad$ (2016), doi:10.1016/j.proeng.2016.11.855

6. E. Nezhnikova IOP Conf. Series: Earth and Environmental Science 90012161 (2017) doi:10.1088/1755-1315/90/1/012161 